\title{
Sociolinguistic approaches to multiethnolect: Language variety and stylistic practice Pia Quist
}

\author{
University of Copenhagen
}

\section{Abstract}

The paper presents the findings of two studies of Copenhagen multiethnolect. The first study depicts a set of linguistic features that constitutes the linguistic variety which is termed multiethnolect. This study was by and large carried out from a perspective which in the paper is called a variety perspective. The second study was carried out from a stylistic practice perspective where multiethnolect is analyzed in more holistic terms as part of a broad range of stylistic repertoires in a local community of practice. The two studies serve in this article as illustrations of different approaches to studying language use and variation in multiethnic urban areas.
Key words

language variety

multiethnolect

stylistic practice

\section{Introduction}

This paper presents the findings from two studies of language use and variation in multiethnic urban Copenhagen. The two studies, conducted in 2000 and 2005, represent two different analytic approaches to studying the speech of bilingual youth in multiethnic urban communities: a variety approach and a stylistic practice approach, respectively. In the first study (Quist, 2000), the speech of second-generation immigrant youth in Copenhagen was examined from the variety perspective; the aim was to find, distinguish, and formally describe a set of linguistic features that were different from standard Danish and associated with immigrant youth. In other words, the goal was to depict particular ways of speaking and to ask whether they represent a new Danish variety or dialect. A more practice-oriented approach to multiethnolectal variation in Copenhagen was applied in the second study (Quist, 2005). In this study, the linguistic variation was viewed and described as part of local stylistic practices in a community of practice.

The two studies presented in this paper serve as illustrations of different approaches to studying language use and variation in multiethnic urban areas. The studies address the questions that can be asked and the answers that can be found: (1) when language use and variation are examined with the goal of describing new emerging varieties and (2) when the goal is to understand linguistic practices and social meaning. The two

Pia Quist, Københavns Universitet, Njalsgade 136, 2300 København S; e-mail:<pqj@hum.ku.dk>. 
approaches are charaterized by some fundamental differences. Thus, their integration is not feasible. However, as will be argued, it is usful to keep both perspectives open if our aim is to describe and understand the use and social meanings of linguistic variation in multiethnic urban areas.

The two studies by Quist $(2000,2005)$ fall within a Scandinavian tradition of research in multiethnolects. A brief exposé of the developments in Scandinavian research shows that the stylistic practice approach of the 2005 study would not have been possible without the previous research that used the variety approach, especially research conducted by Ulla-Britt Kotsinas in the $1980 \mathrm{~s}$ and $1990 \mathrm{~s}$.

In addition to the description of the two studies of Copenhagen multiethnic speech, another issue will be emphasized in this paper: Multiethnolects are integrated parts of the Copenhagen linguistic landscape and cannot be fully understood if they are separated and isolated from the dialectal space in which they have developed and are used. It will be argued that this conclusion is a result of combined insights from both studies.

\section{The term 'multiethnolect'}

A multiethnolect is a linguistic "something," a variety or style, which has developed in multiethnic urban communities and which is associated with speakers of mixed ethnic groups. The prefix "multi' indicates the contrast to an "ethnolect," the speakers of which typically constitute one minority group. Michael Clyne (2000, p. 87) writes about this "something": it "may be termed 'multiethnolect' because several minority groups use it collectively to express their minority status and/or as a reaction to that status to upgrade it." He (in agreement with others, e.g., Kotsinas, 1988 and Quist, 2000, 2005) notes that: "In some cases, members of the dominant (ethnic) group, especially young people, share it with the ethnic minorities in a 'language crossing' situation." A "lect" term, like multiethnolect, implies a (more or less focused) set of linguistic features that separates it from a standard language or other "lects." This is probably the reason why a "lect" term in the case of young immigrant speech is often disputed and sometimes avoided by linguists (cf. for instance Fraurud \& Bijvoet, 2004). However, "multiethnolect" in this paper is used as a broad term for the type of linguistic variety/style that Clyne is referring to.

\section{Multiethnolects in Scandinavia}

Ulla-Britt Kotsinas was the first Scandinavian linguist to draw attention to multiethnic adolescent speech. As early as the beginning of the 1980 s, Kotsinas posed the question whether the speech of Swedish immigrant adolescents forms a new Swedish dialect (Kotsinas, 1987, 1988). She argued — and verified — that the ways in which the speech of adolescents in Rinkeby (a multiethnic suburb of Stockholm) differed from standard Swedish were not a result of poorly acquired Swedish. Their speech could not be understood as an interlanguage, but ought to be regarded as a new Swedish dialect (Kotsinas, 1987, p.276). One of Kotsinas' main arguments in favor of this was the fact that the speakers of Rinkeby Swedish - as the variety was called among its users - were able to shift language style according to situation and interlocutors (Kotsinas, 1992, 
p. 52). Kotsinas' study of Rinkeby Swedish was the focus of a great deal of attention in Scandinavia, both among linguists and in the media (Fraurud, 2004). But her research was not followed by other Scandinavian linguists until much later. For about a decade, there was only anecdotal evidence of phenomena similar to Rinkeby Swedish, and no follow-up study in the suburbs of, for example, Malmö or Copenhagen. One exception, though, was a master's thesis, from Oslo University, by Stine Aasheim reporting on so-called Kebab Norwegian (Aasheim, 1997). The thesis examined a list of about 150 lexical loans from different immigrant languages, for example, Turkish, Arabic, Berber and so forth, and was the first Norwegian account of new multiethnolects.

It is no coincidence that the first Scandinavian study of multiethnolectal speech was conducted in Sweden. Sweden experienced a greater degree of immigration at an earlier time than did the other Scandinavian countries, and the city of Stockholm developed linguistically diverse neighborhoods before Oslo and Copenhagen did.

Although path-breaking, Kotsinas' study called for follow-up investigations. Fraurud (2004) requested more empirical evidence, and discussions on whether the adolescents' speech should be called a dialect, an interlanguage, a youth style or something else continued (Bodén, 2004; Fraurud \& Bijvoet, 2004). In 2002, a large Swedish research project took up the challenges and set itself to investigate the "language and language use among young people in multilingual urban settings" in Stockholm, Gothenburg, and Malmö. In an attempt to avoid discussions on how to term the linguistic phenomena like Rinkeby Swedish, the researchers agreed to refer to their object of study as "Swedish on multilingual ground" (SMG). Among the many substudies in this large project is Petra Bodén's acoustico-phonetic study of SMG in Malmö (by its speakers called Rosengård Swedish; Bodén, 2007). Bodén concludes on the basis of a listening test with 108 participants that "SMG clearly can be spoken by speakers without an immigrant background, that is, by speakers with Swedish as their (only) L1," and that "SMG speakers can codeswitch between Rosengård Swedish and some other form of Swedish" (Bodén, 2004, p.477). These two results are in line with Kotsinas' early arguments, and Bodén therefore concludes that SMG is not an expression of poorly acquired Swedish, but can be seen as a language variety parallel to other Swedish youth varieties and dialects.

There is also evidence that multiethnolectal speech, similar to Rinkeby Swedish and Copenhagen multiethnolect, has developed in Oslo ${ }^{2}$. New Norwegian research (the UPUS project) is going to study, among other things, syntactic, lexical, and phonological characteristics of Norwegian multiethnolectal speech. ${ }^{3}$

In Denmark, multiethnolectal speech studies have not been confined to Copenhagen. In Århus, the second largest city in Denmark, Mette Vedsgaard Christensen conducted a study of "Language use and language choice among adolescents in multiethnic areas" (author's translation) (Christensen, in preparation). Christensen reports that most linguistic influences in the area of interest (a neighborhood called Gjellerupparken) come from Arabic languages. Hence, Christensen calls the variety in question an "ethnolect."

$1<$ http://hum.gu.se/institutioner/svenska-spraket/isa/verk/projekt/pag/sprakbruk_eng/>.

2 As, for example, discussed and presented by Ingvild Nistov, Torild Opsahl, Finn Aarsæther, Bente Ailin Svendsen, and Unn Røyneland at the SONE/UPUS conference in Kristiansand, 2006.

$3<$ http://www.hf.ntnu.no/hf/adm/forskning/prosjekter/UPUS/index.html>. 
In a comparison of L2 (ethnolect) speakers and L1 (nonethnolect) speakers, Christensen finds that the L2 speakers - in their ethnolect - use significantly more local Århus dialect features than do the L1 speakers (Christensen, in preparation). This important finding underlines one of the main arguments of this paper, namely that (multi-)ethnolect is an integrated part (or practice) of local speech communities - something that cannot be understood (only) as a marker of ethnic identity in contrast to a majority identity, but rather ought to be seen as integrated in the local linguistic and social landscape.

\section{Multiethnolect-a variety}

Most of the studies mentioned in the previous section are partly driven by a dialectological perspective in the sense that they attempt to give a formal description of a variety in relation to a standard language. As mentioned, Kotsinas' research in the $1980 \mathrm{~s}$ primarily centered on "Immigrant children's Swedish - a new variety?" (the title of Kotsinas, 1988) The first study of multiethnolect in Copenhagen was inspired to a large extent by Kotsinas' study and approach, that is, the research question was whether a new speech variety was emerging in multiethnic areas of Copenhagen, and whether it was possible to talk about a new Danish dialect (Quist, 2000, p. 145, p. 181).

Quist's study from 2000 was based on short-term ethnographic inquiries in two different youth clubs and a high school, all located in different multiethnic areas of Copenhagen (Avedøre, Vesterbro, and Nørrebro). The data set consisted of interviews, group recordings and recordings made by six speakers who recorded themselves in various informal situations at school, in a youth club and at home. The group of recorded speakers represented different first languages, namely Berber, Turkish, Kurdish, Arabic, Danish, Urdu, and Serbian. However, at all three institutions, there were speakers of other languages as well, for example, Somali, English, Norwegian, and Hindi. The participants from the youth clubs were between 12 and 16 years old, and the high school students were about 17 years old. An overview of the recorded data is provided in Table 1.

\section{Table 1}

Types of data and mother tongues of the participants. All names are pseudonyms

\begin{tabular}{|c|c|c|c|}
\hline & Youth club, boys & Youth club, girls & High school \\
\hline Self-recordings & $\begin{array}{l}\text { Ahmed, Berber } \\
\text { Erchin, Turkish }\end{array}$ & $\begin{array}{l}\text { Mirca, Serbian } \\
\text { Malene, Danish }\end{array}$ & $\begin{array}{l}\text { Rina, Arabic (Palestine) } \\
\text { Morten, Danish }\end{array}$ \\
\hline $\begin{array}{l}\text { Group recordings } \\
\text { (during a board } \\
\text { game) }\end{array}$ & $\begin{array}{l}\text { Ahmed, Berber } \\
\text { Erchin, Turkish } \\
\text { Dawood, Urdu } \\
\text { Sevki, Kurdish (Tur.) } \\
\text { Hasan, Turkish }\end{array}$ & $\begin{array}{l}\text { Mirca, Serbian } \\
\text { Fadime, Kurdish (Tur.) } \\
\text { Serife, Kurdish (Tur.) } \\
\text { Solaima, Kurdish (Iraq) }\end{array}$ & $\begin{array}{l}\text { Rina, Arabic (Palestine) } \\
\text { Morten, Danish } \\
\text { Ravin, Urdu } \\
\text { Anne, Danish } \\
\text { Usma, Urdu }\end{array}$ \\
\hline $\begin{array}{l}\text { Retrospective } \\
\text { interview }\end{array}$ & $\begin{array}{l}\text { Ahmed, Berber } \\
\text { Erchin, Turkish }\end{array}$ & - & $\begin{array}{l}\text { Rina, Arabic (Palestine) } \\
\text { Morten, Danish }\end{array}$ \\
\hline
\end{tabular}

The study resulted in a description of a set of linguistic features that were used by and associated with the immigrant adolescents and that, it was argued, formed a new 
Copenhagen speech variety. The linguistic features were of syntactic, morphologic, lexical, and phonetic nature. Most of the features resemble those that Kotsinas found in Rinkeby Swedish. They include the following:

- Morphology. An extended use of the common gender where standard Danish has the neuter. This is apparent both in indefinite articles, for example, en job, which in standard Danish is et job, (in English: a job), and in definite demonstratives, for example, den der blad, den der projekt which in standard Danish is det der blad, det der projekt (in English: that magazine, that project).

- Syntax. Occurrences of SV word order in contexts where standard Danish has inversion, VS. For instance, normalt man går på ungdomsskolen and når man er $i$ puberteten man tanker mere. In standard Danish it is normalt går man på ungdomsskolen and når man er i puberteten tonker man mere (in English: normally you attend the youth club; when you reach puberty you think more).

- Lexicon. A group of 20 to 30 loanwords from Turkish, Arabic, Kurdish, and Serbian. Most of them are taboo and slang words or words used as intensifiers and discourse markers. Some of the most frequent ones are:

ew apparently from Kurdish. It is used as a marker to attract attention, like 'hey' or 'hello'

kız from Turkish meaning girl, for example, efter den der fest jeg tanker bare på fest og $\underline{k l z}$ (in English: after that party I only think about party and $\underline{k l z}$ ). In this example, the speaker does not use $k ı z$ in the plural, kızlar, although the plural form also appears in multiethnolect

jalla from Arabic meaning come or come on (imperative), for example, jalla vi skal købe noget (English: jalla we are going to buy something)

para from Turkish meaning money

pička a taboo word from Serbian meaning 'cunt', used for 'prostitute' as an insult

wallah from Arabic meaning something like 'I swear by (the name of) God'. This is the most frequent lexicon characteristic of multiethnolect. It can be used for different purposes. Compare, for example, the following exchange between Ahmed and Mehmet:

Ahmed: $\quad$ Jeg så Sabrina i dag (I saw Sabrina today)

Mehmet: Wallah?

Ahmed: $\quad$ Ude foran bussen (next to the bus)

Mehmet: Wallah?

Ahmed: Wallah.

The first two times 'wallah' is used by Mehmet, he pronounces them with a rising intonation indicating that he is asking a question: "is it true?" Ahmed repeats "wallah," but pronounces it with a falling intonation and thereby confirms: "yes, it is true." 
Wallah is also often used as an intensifier to underline the importance or value of a statement, for example, Wallah jeg siger dig min storebror skylder mig 700 kroner (English: Wallah, I tell you my older brother owes me 700 crowns). Furthermore, wallah often appears in fixed phrases like wallah jeg svarger (English: wallah I swear) and wallah billa (=Arabic, billa is a contraction of bi ism Allah, meaning in the name of God).

- Pronunciation. Although multiethnolectal pronunciation appears to be distinctive and easy to recognize both by users and nonusers, it has so far not been possible to provide a thorough description of what it is that actually makes it sound different from standard Danish. In Quist (2000), multiethnolect is described as diverging from standard Danish in terms of a different distribution of stress. Standard Danish is usually described as "stress-timed," whereas multiethnolectal prosody seemed to follow a more "syllable-timed" stress pattern, that is, a difference between fewer but stronger stresses in standard Danish and more but weaker stresses in multiethnolect. This difference is probably the main reason why multiethnolect sounds monotonous and staccato-like to a standard Danish speaker. However, a syllable-timed stress pattern may not be the only explanation for the characteristic sound of multiethnolect. In a recent study, Hansen and Pharao (2005) show that vowel length probably also influences the perception of multiethnolect pronunciation as staccato. Comparing speakers of multiethnolect and speakers of "young standard Copenhagen," Hansen and Pharao found a systematic difference between pronunciations of the contrast between long and short vowels in stressed and unstressed syllables. Except for words with schwa in the second syllable, speakers of multiethnolect had much shorter vowels than did speakers of "young standard Copenhagen" (Hansen \& Pharao, 2005, p. 23). Another recurring feature that also catches the attention of speakers of standard Danish is the absence of stød. Danish stød is a word accent realized as a glottal constriction. Speakers of multiethnolect tend to omit stød where speakers of standard Danish usually pronounce it, for example, in words like tusind, where the standard has stød on $\underline{\mathrm{u}}$ (in English: thousand), sammen and grim where the standard has stød on $\underline{\mathrm{m}}$ (in English: together, ugly).

In addition to the linguistic findings of Quist (2000), the study shows a manifest awareness among the participants of their speech style as a specific "language" (their words, et sprog 'a language'). They formulated opinions and attitudes about its use — by whom and in what situations - and they talked about it as something distinct from "normal Danish" and also different from the Danish language of their first-generation immigrant parents. Different names, like perkersprog ${ }^{4}$ and wallahsprog, were used to refer to the reported way of speaking, but there did not seem to be one common name (as was apparently the case for Rinkeby Swedish). Hence, the term 'multiethnolect' was chosen to describe and refer to the new speech variety. There were a couple of reasons for this. First of all, multiethnolect indicates that the variety is not linked to just one ethnic

4 Perkersprog consists of the words perker and sprog. Sprog means language. Perker is a derogatory term for immigrants, used in somewhat the same way as nigger in American English. The adolescents themselves sometimes call each other perker, but an outsider should not use this terminology. 
group. It is a result of a multiethnic situation in which speakers have different ethnic backgrounds (including Danish ethnic background) and different first languages (e.g., Turkish, Somali, Danish, Arab, Serbian). A multiethnolect therefore is not an ethnolect like, for instance, Turkish-German (reported on by Auer, 2003 and Dirim \& Auer, 2004), which is associated with one ethnic group and draws on only one minority language. Copenhagen multiethnolect is generally not associated with, say, the Copenhagen Turks or Moroccans, but more broadly with Danish adolescents of immigrant backgrounds. Secondly, the use of a "lect" term signals that this is a parallel phenomenon to other "lects" like sociolects, dialects, chronolects, and so forth, and it ought to be regarded as such, that is, as something mundane and not "exotic." Outside of academia, in a Danish national context, this is arguably strategically and politically important.

\section{Variety or practice?}

Before the presentation of the recent study of multiethnolect as stylistic practice, we shall briefly contrast the variety approach to multiethnolect with an approach here called a stylistic practice approach. Whether ethnolects are viewed as linguistic varieties or stylistic practices is a question of perspective. Studies that take a variety approach aim to provide a formal description of the speech of immigrant adolescents in relation to a standard, national language. Studies that take a practice approach focus on the ways in which the speech of young immigrants is used as a resource for self-positioning in a social space. Speech therefore is looked at and analyzed within a local system of semiotic contrasts in a local community of practice. The broad categories of bilinguals and native speakers (L2 and L1 speakers) are the independent variables in the variety approach. These are contrasted in order to provide a categorical background for the linguistic description of linguistic contrasts. The variety approach does not seek to understand the nature of these categories, how they interact, work, and construct each other. In contrast to this, in the stylistic practice perspective, it is crucial to treat such "given" categories critically. Categorical identities are viewed as negotiable and constructed, and the analyses focus on processes in which language and identity interrelate and shape social meaning.

The two approaches thus answer different kinds of questions. The variety approach contributes to the description of variation in the speech community and it helps us to find out if there is anything linguistically systematic going on at all. The stylistic practice approach, on the other hand, is a way to examine the social meanings, functions, and consequences of the speech of the adolescents.

Kotsinas' first studies of young immigrants' speech used the variety approach. There is a historical reason for this. Kotsinas wished to raise awareness in linguistics, and in academia in general, about youth immigrant speech as something acceptable — and even recognizable. Up to that point, it was only researchers interested in second language acquisition and language pedagogy who had dealt with Scandinavian bilingual youth. Kotsinas, like everybody else working with this topic, was up against strong normative forces - for example, teachers, who would (could?) only see bilingual children's and adolescents' language as learner language or interlanguage. Kotsinas demonstrated convincingly, with the variety approach, that Rinkeby Swedish is not an interlanguage. It made sense to describe the Stockholm immigrant adolescent speech in contrast to 
a Stockholm standard norm and, consequently, to include immigrant adolescents in Scandinavian sociolinguistics and dialectology (Kotsinas, 1987, 1988).

Kotsinas prepared the way for the first Copenhagen study (Quist, 2000). Without her showing that it is possible to treat immigrant youth speech as a variety in its own right, it would not have been possible — at that time in 1998 when the study was launched — to conduct a similar study in a Copenhagen context. Also, the questions and answers that were raised from the 2000 study beat the track for a practice-oriented study, that is, the 2005 study. The variety approach showed us that there is indeed something systematically going on with the speech of immigrant youth in Copenhagen - something that meaningfully "fits" the linguistic boxes already shaped for descriptions of dialects and varieties; and something that we could name and talk about as a linguistic phenomenon, well-known to dialectologists and sociolinguists, but different from what otherwise was thought of as "incomplete" learner language.

The variety perspective therefore can be seen as a "step along the way" from studying bilingual youth as learners, to a situation where it is acceptable and acknowledged that bilingual speakers should be treated the same as every other speaker in the speech community. Still, there are various disadvantages connected with the study of multiethnic speech as varieties. For instance, the approach that was taken by Kotsinas and by Quist (2000) tended to isolate the multiethnic variety from the social and sociolinguistic space in which it was used. In general, the variety approach disregards the fact that the spaces in which multiethnolect has emerged are heterogeneous spaces in very complex ways. It is not the case that the immigrant speakers live in harmonious, nonstratified areas; and it is also not the case that their ways of speaking result from inward solidarity signaling processes. In the ethnically mixed areas of Copenhagen, ethnicity (and bilingualism) crosscuts all kinds of status groups with different lifestyles, backgrounds and ways of living (old and young people, workers, shop owners, academics, drug addicts, artists etc. live side by side). Everybody engages in many different - and some of them very complex - communities of practice, for example, the local schools. Multiethnolect has emerged from such heterogeneous urban areas, within a complex relational stylistic space, where there is no simple one-to-one relation between speaker background and language, and between place and language. A variety approach — in the way it has been carried out thus far - is not able to incorporate these complexities that characterize many of the urban multiethnic communities. In order to do that, we need a locally based study of how linguistic resources of "sounding like an immigrant adolescent" relate to other linguistic and stylistic resources in a heterogeneous community of practice.

\section{Multiethnolect—stylistic practice}

A more practice-oriented approach to multiethnolect and language variation in inner Copenhagen was adopted in the recent multiethnolect study (Quist, 2005). One of the purposes of this study was to leave the variety approach for a while and instead look at how young immigrant speech forms part of a multiplicity of stylistic resources. But before the findings from that study is presented in more concrete terms, it should explicitly be described what is meant by stylistic practice. In short, stylistic practice is the process through which signs and differences become meaningful resources in daily enterprises 
and activities (Quist, 2005, p.75). Stylistic practice covers the processes that connect different resources (linguistic and nonlinguistic ones) in meaningful relationships in association with the participants' identity negotiations. Multiethnolectal features are examples of resources that become socially meaningful in stylistic practice. Style, in this context, is a cluster of resources, including linguistic resources, which is made socially meaningful in relation to other clusters of resources (Quist, 2005, p. 76). Thus, style in this definition is understood in holistic terms as a collection of different types of resources, including body resources and aesthetic resources in addition to linguistic resources. This definition is inspired by Penelope Eckert's concept of style: "a clustering of linguistic resources and an association of that clustering with social meaning" (Eckert, 2001, p.123) - although Eckert here, in this definition, only includes linguistic elements in the clustering. The idea of the Quist (2005) study is to place linguistic resources (e.g., multiethnolectal resources) in a broad context together with other stylistic elements. The seven style clusters, which are described below, are a (analytic) result of this understanding of and approach to style.

The 2005 study is based on five months of participant observation at a high school in inner Copenhagen, more precisely at Metropolitanskolen in Nørrebro, an area famous for its relatively large number of immigrants. Ethnography is central to the study because it is believed that in order to examine the construction and organization of the social meaning of linguistic variation we need to know about the local context and local uses of linguistic resources. The approach is inspired by Eckert's work, in which the idea (and ideal) is to discover social meanings and categories, instead of presupposing them (Eckert, 1996, 2000, 2001).

The participant observation focused on 54 high school students in two classes 5 . They were observed, interviewed, and recorded during school lessons, breaks, a couple of parties and at a school camp. The students were 15-16 years old. There was an almost equal proportion of boys and girls, of students with Danish ethnic background and ethnic backgrounds other than Danish, and of students focusing on "math" and students focusing on "language" 6 . Table 2 provides an overview of the data set.

\section{Table 2}

\section{Types of data reported by Quist (2005)}

Approx. 5 months of participant observation

Approx. 150 pages field diary

Approx. 200 drawings

52 interviews

10 group recordings (5 participants in each)

Self-recordings from 7 speakers

46 questionnaires

Screening tests, written essays and more...

5 The school class is important in Danish high school students' lives. Ninety percent of all activities take place in the class with the same people.

6 Danish high school students choose if they want to join a so-called "language class" or a "math class." The study followed one "language class" and one "math class." 


\section{Style clusters}

Multiethnolect is a common and well-known linguistic resource in Metropolitanskolen. Some students use it a lot, others only sometimes, and others would never - unless jokingly - use multiethnolect. In the following, we describe those who, among the 54 individuals in the study, employ multiethnolect, and see how multiethnolect forms part of stylistic practices in this particular community of practice.

The study identifies seven style clusters: three masculine and four feminine clusters. A style cluster is a collection of signs that in the course of time cluster together, that is, they are performed in regular patterns by the members of the community of practice. Members can (and do) perform resources from different clusters. In the registration of signs that cluster together, the notion of sign is addressed in a broad sense, for example, as body-signs (gendered and racial), signs of school attitude, physical positioning in the school area, preferences for music, clothing, and so on. The style clusters illustrate that there are regular concurrencies of features that, in the course of time, make it possible to create stylistic meaning. A sign becomes meaningful as soon as it is recognized as a part of a repeated pattern, that is, as part of a shared repertoire of the community of practice (Wenger, 1998, p.73). The clusters should not be confused with groups; an individual does not belong to a cluster, but rather performs a style and that way constitutes it - through daily acts and practices.

Let us look at style Cluster 1 as an example (cf. Quist, 2005, p. 257):

\section{Table 3}

\section{Style Cluster 1}

White skin, masculine body sign; "Dane"; show no to little interest in class teaching; use computers for games, chat, and music; smoke; leave the school premises during lunch breaks; drink alcohol and talk about it in class; wear hip-hop clothes/baggy jeans and large T-shirts; images of naked women on laptop screens; listen to hip-hop and rock music.

Long affrication of $(\mathrm{t})$. Frequent use of 'lexis' - mostly slang and swear-words.

No use multiethnolectal features.

Style Cluster 1 is primarily performed by boys with white skin; that is, those who are recognized as "Danes" ('Danes' and 'foreigners' are the high school students' own terms). They show little interest in official school activities (they rarely do their homework and are relatively passive during class lessons). All the students in the study have personal laptops which they use for school related as well as leisure time related activities. The boys who perform style Cluster 1 use their laptops primarily for games, music, and communication (e-mail, chat, and messaging). On the computer screens they typically display images of half-naked women, pin-ups. They also use their computers to search for and share music, mostly hip-hop and rock music. These boys smoke cigarettes, so they go to the outdoor smoking areas during the breaks, and they leave the school 
premises during lunchtime. They drink alcohol and talk about alcohol at school. The clothes they wear are a sort of hip-hop style with baggy jeans and large T-shirts. Among the analyzed linguistic resources these boys had the longest affrication of word initial $(\mathrm{t})$, they used more slang and more swear-words than did the others, and they never used multiethnolect, except with instances of parody. (For details about the specific style features, see Quist, 2005, Chapters 9 to 14.)

Style Cluster 1 and the other six style clusters were developed through a comparison of the examined features. In order to illustrate this process of analysis, we can look at Figure 1, which is an abstraction of the body movements in the two high school classes seen from a bird's eye view.

\section{Figure 1}

Body positions in time and space

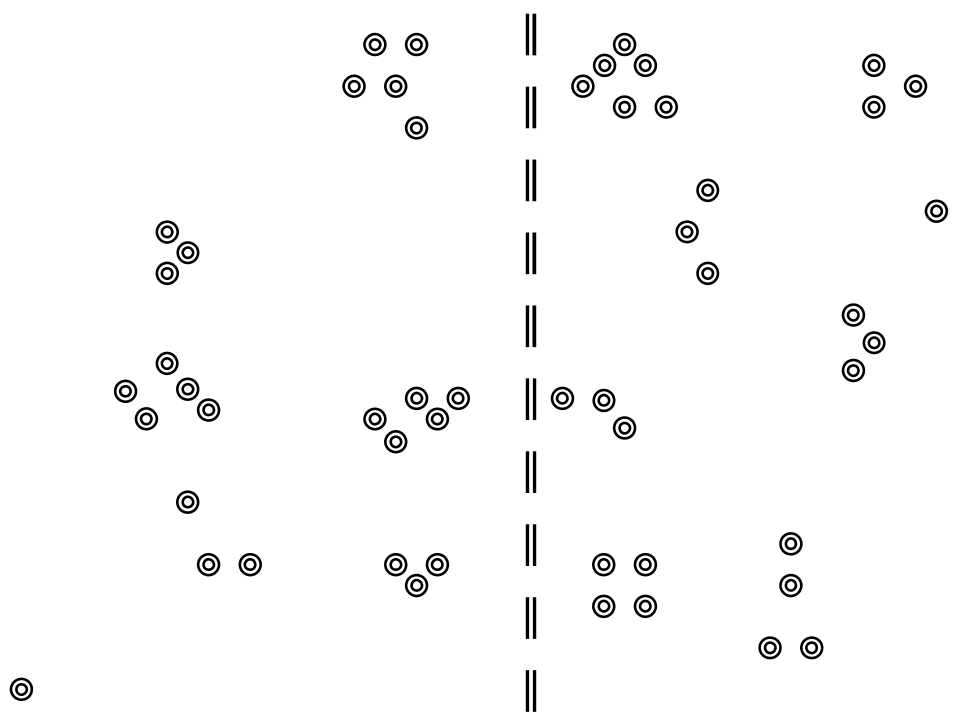

A circle signifies a body and the position of that body vis-à-vis other bodies in the classes. The "language class" is to the right of the broken line and the "math class" is to the left. During the five months of participant observation, every person's positions within the school area were registered - in the classrooms, hallways, school yard, and so forth. The regularities of the positions (i.e., how they sat in the same places in the classrooms, how they went to the same places within and outside of the school area, etc.) make it meaningful to illustrate the patterned movements as in Figure 1, which, in short, is a condensation of body movements in time and space.

As can be seen from Figure 1, the bodies moved in clusters, close to or far from each other. A couple of the bodies do not move in closeness to other bodies (the "outsiders," cf. Quist, 2005, p.132), but the majority move in more or less stable groups. 


\section{Figure 2}

Feminine and masculine clusters

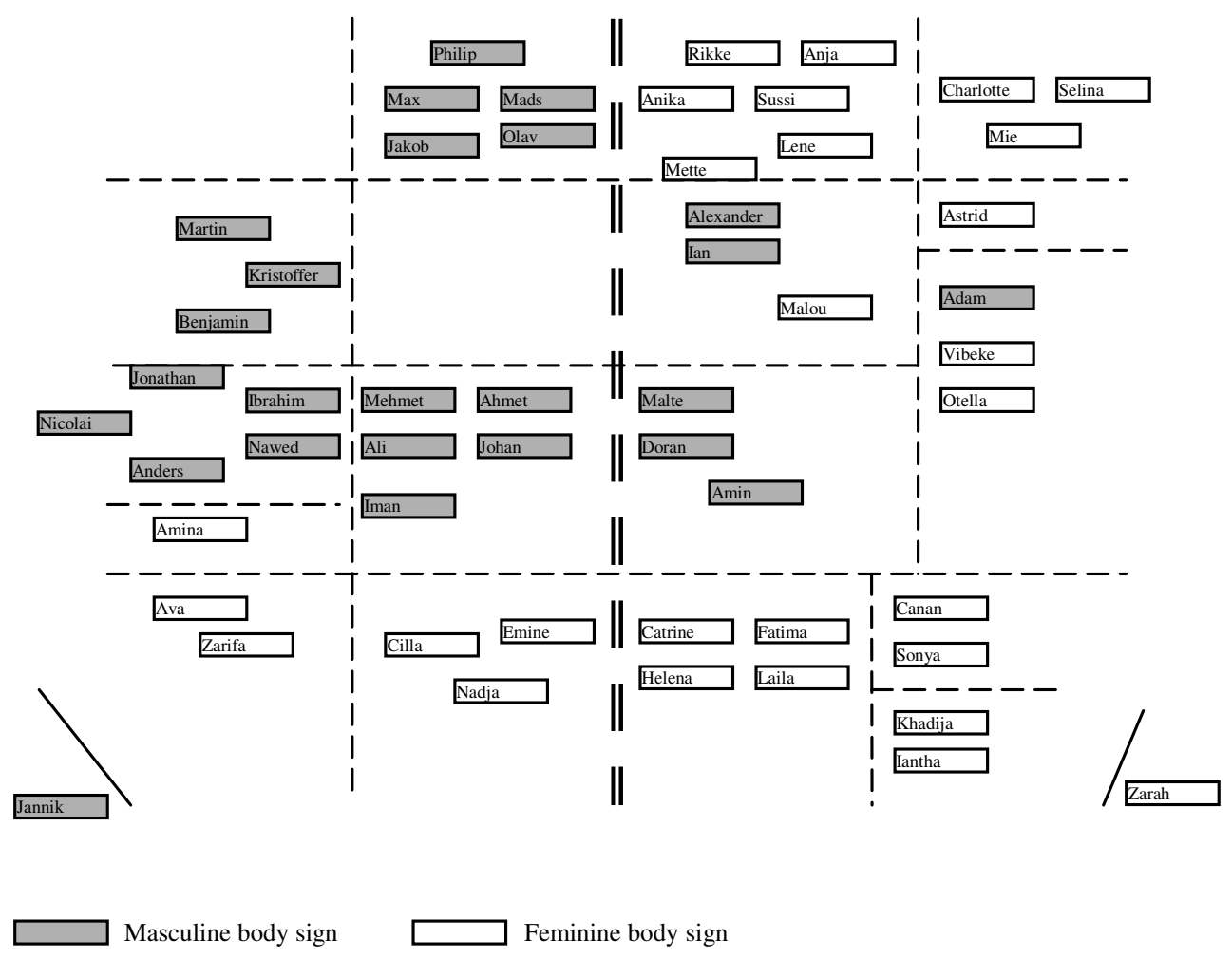

From the bird's eye view, however, we cannot see who is (seen as) a boy or girl, who has brown skin, blond hair, who wears a veil, and so forth. By plotting in all such different types of signs, we can get an overview of how they cluster together. Let us take gendered body signs ${ }^{7}$ as an example. Figure 2 shows us that the general pattern is that boys move around in closeness to other boys, and girls in closeness to other girls (Malou and Adam are the only exceptions).

We can make the same type of sociogram with a very different type of sign, for example, smoking. In Figure 3, the gray rectangles signify those who smoke, the white ones those who do not smoke, and the dotted square signifies a person who only smokes at parties.

From Figure 3, we see that there is a group of smokers in the "math class" who hang out together (Olav, Mads, Philip, Max, Jakob), a group of smokers in the "language class" (Alexander, Ian, Malou + Malte, and Doran), and a few smokers distributed across three other groups in the landscape. Although the sociograms give a static picture of something which is inherently dynamic, they do give us an idea of patterns and regularities in the

7 For more on the notions of masculine/feminine body signs see Søndergaard 2000. 
stylistic practices in the two high school classes. Comparing Figures 2 and 3, it is for instance clear that there are at least two groups of boys who move in closeness to together, and who smoke. In fact, these boys are the typical performers of style Cluster 1.

\section{Figure 3}

\section{Smokers and nonsmokers}

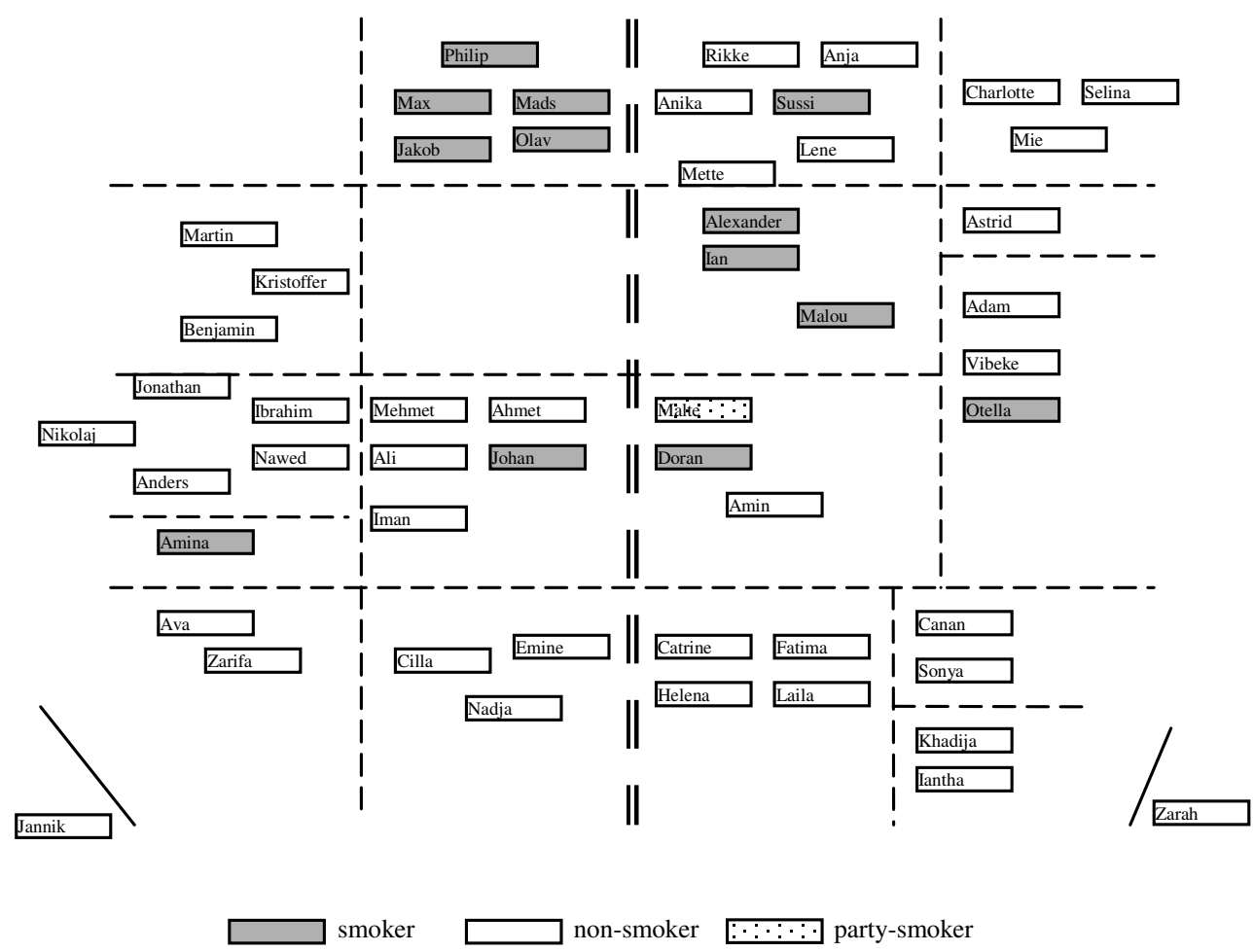

\section{Multiethnolect in the social landscape}

Now, how is multiethnolect distributed across the style clusters in the social landscape of the high school classes? Several data sets were drawn upon in order to answer this question: observations/field notes, questionnaires, and recordings (see Table 3). Without going into the linguistic characteristics of the multiethnolect used at Metropolitanskolen, we shall here simply distinguish between those who use and those who do not use multiethnolect (for details about this analysis see Quist, 2005, p. 250) ${ }^{8}$.

8 It should be noted that the "use of multiethnolect" in this paper only implies use that is not parodic or what could be called "mock multiethnolect." Parodic use of multiethnolect is certainly common in this community of practice, and is also integrated in stylistic practices, but it is beyond the scope of this paper to include it. For analyses of parodic use of multiethnolect see Quist and Jørgensen, 2007 and Quist, 2005 chapter 17. 
Out of 54 students, 16 use (nonparodic) multiethnolect as part of their linguistic repertoire, namely Ian, Mehmet, Ahmet, Malte, Johan, Doran, Iman, Amina, Cilla, Emine, Nadja, Catrine, Helena, Fatima, Laila, and Sonya. These students are marked with gray rectangles in Figure 4.

\section{Figure 4}

Users and nonusers of multiethnolect

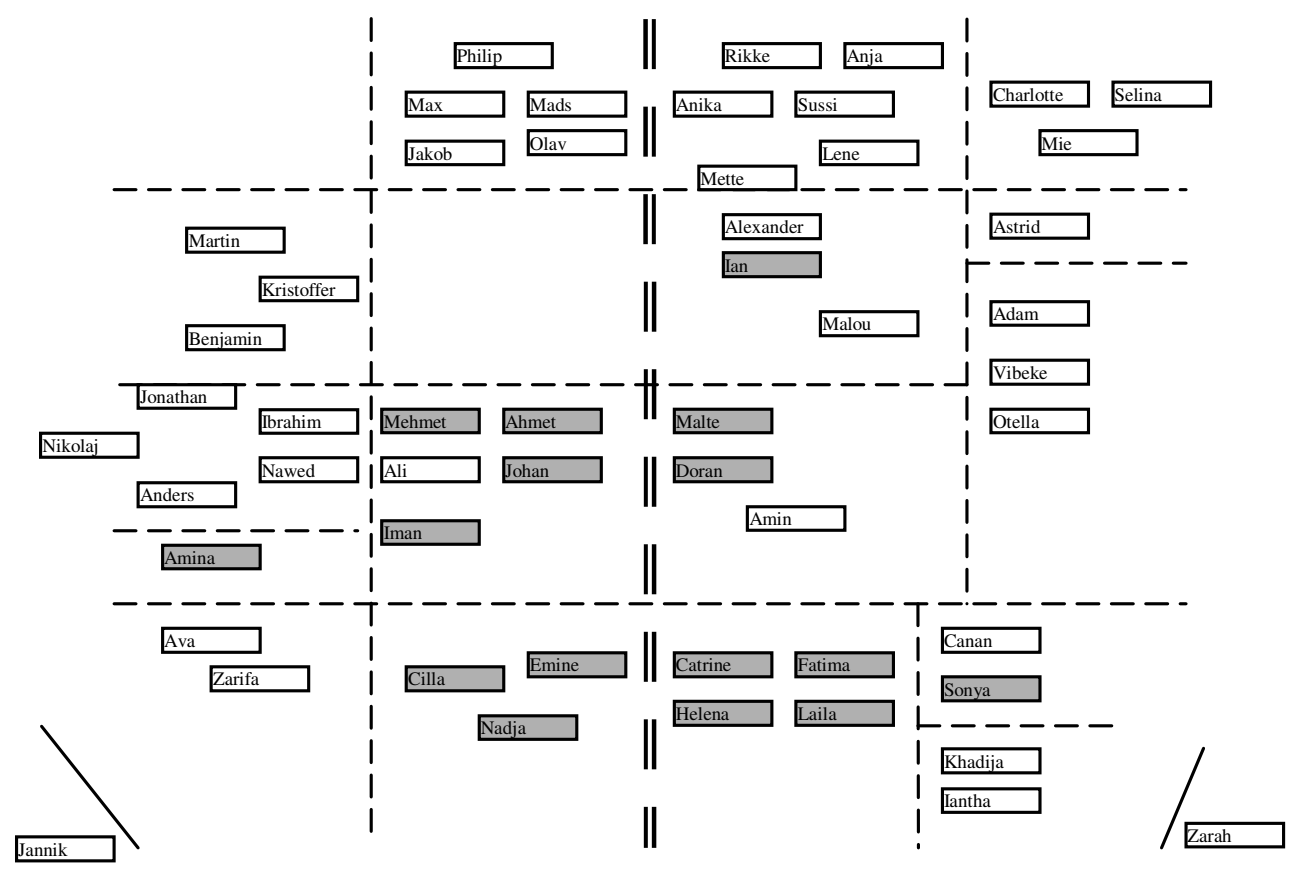

\footnotetext{
$\square$ Multiethnolect is part of this person's linguistic repertoire
$\square$ Multiethnolect is not part of this person's linguistic repertoire
}

Those who use multiethnolect move in regular patterns in closeness to each other. Some of them form rather stable groups of friends (those located in the lower middle part of the chart). In the upper and outer parts of the chart, we find groups of students who do not have multiethnolect in their linguistic repertoire.

If we compare this pattern with the style clusters, we find that multiethnolect clusters with a range of other signs and resources. Figure 5 is an attempt to map the style clusters onto the social landscape. It obviously is a rough abstraction since the style clusters are collections of many different signs. However, the chart gives us an idea of who the core performers of the different style clusters are, and by comparing this chart with Figure 4, one can see that multiethnolect clusters with style Clusters 2 and 6 (this can also be seen in the listing of all 7 style clusters in the Appendix to this article). 


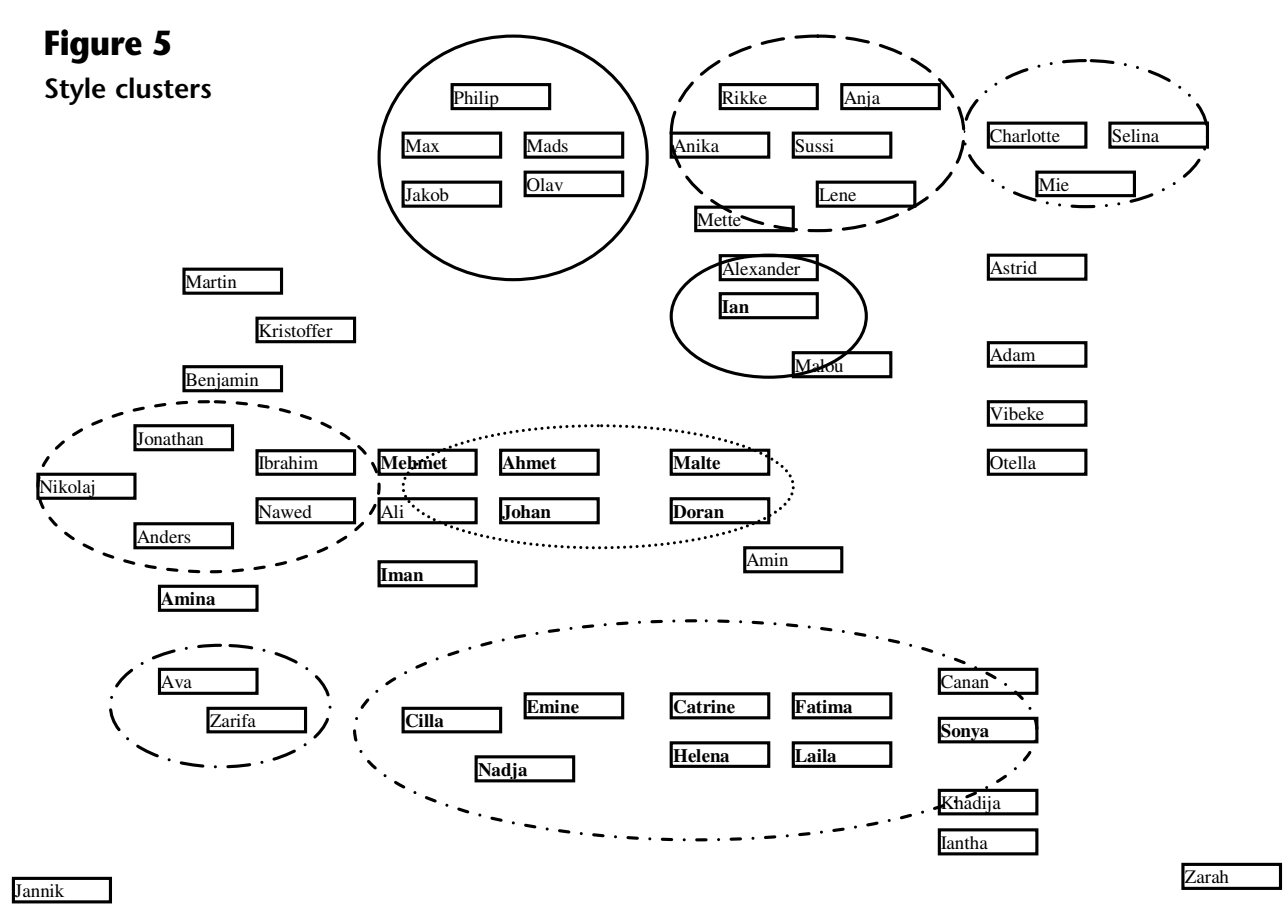

Style Cluster 2 is primarily performed by boys who are called and who call themselves "foreigners" (udlonding in Danish). They show little interest in official school activities; they use their laptops for games, chat, and music; during breaks they hang out in the hallway between the classrooms; they display images of cars on their laptop screens; they mostly wear polo-shirts and jeans; and their preferred music is popular radio chart hits. A further common feature of this cluster is the use of multiethnolect.

If we compare this style cluster to style Cluster 3, we find some striking differences. Style Cluster 3 is performed by the school enthusiastic boys (those who in some ways resemble the "jocks" in American high schools, Eckert, 1989). They are all boys, but there is no systematic pattern with regard to ethnicity — both boys with a Danish ethnic background and boys with backgrounds other than Danish perform this cluster. They clearly signal involvement in class teaching; they primarily use their laptops for school work; they do not smoke; they stay in the classroom during breaks; they do not drink alcohol; and they never use multiethnolect.

Ibrahim and Nawed are core representatives of style Cluster 3. They are of Arabic descent, but they do not use multiethnolect. Johan and Malte, on the other hand, are typical performers of style Cluster 2, despite the fact that they are blond and are not considered "real foreigners." They have Danish ethnic backgrounds, and they use multiethnolect. Thus, in the cases of Ibrahim, Nawed, Johan, and Malte, there is no straightforward relation between ethnic background and the use of multiethnolect. Although race and ethnicity do seem to work as distinguishing factors (for instance between style Clusters 1 and 2), other aspects too connect to the use of multiethnolect in stylistic practices. We find a somewhat parallel to this in the feminine style clusters. Style Cluster 6 is primarily performed by girls with ethnic backgrounds other than 
Danish, and it is different from, for example, style Clusters 4 and 5 in that the use of markers of non-Danish ethnicity is typical for this cluster (markers such as clothing, preferred music, idols, films etc.). A typical performer of style Cluster 6 is Catrine who, like Johan and Malte, is blond and looks "Danish," still she employs multiethnolect in her linguistic repertoire. In contrast to this are the performers of style Cluster 7, the school enthusiastic girls Ava and Zarifa, who are of Arabic descent and who never use multiethnolect.

\section{Conclusions}

The account of who at Metropolitanskolen uses multiethnolect as part of their linguistic repertoire shows that multiethnolect is associated with the style clusters 2 and 6 (see Appendix), whereas the five other style clusters are characterized by not having multiethnolect as a part of their repertoire. This leads to at least two conclusions. Firstly, multiethnolect combines as a stylistic resource with a series of other signs and resources. Even though race and ethnicity do play a role in this community of practice, there is no clear one-to-one correspondence between ethnic background and the use of multiethnolect. For example, in the study, among others, Ibrahim, Nawed, and Ali have ethnic backgrounds other than Danish; they never use multiethnolect (Ibrahim and Nawed are typical performers of style cluster 3); and yet Malte, Johan, and Catrine with Danish ethnic backgrounds use multiethnolect (they are typical performers of style Clusters 2 and 6) (for interaction analyses of this, see Quist, 2005, ch. 16 and 17). Secondly, the analysis shows that multiethnolect "lives" side by side with other variants of spoken Danish. It is not the case that (as some might think) multiethnolect exists as a "secret code" used by speakers in isolated groups that do not interact with other nonusers. Multiethnolect is an integrated part of Copenhagen communities of practice. Hence, there is no one-to-one correspondence between the geographical place and language use either. It is not possible to describe the speech in Nørrebro as one variety (as for instance is normally done in a traditional dialect study); and it is not possible to point out a proto-typical Nørrebro-speaker. Heterogeneity seems to be the norm, though it is heterogeneity practiced in systematic ways. It is therefore important to emphasize that multiethnolect can not be understood in isolation from the dialectal and social space in which it is used and has developed. Multiethnolect is not a result of the acts of isolated groups of speakers, neither is it a more or less automatic outcome of language contact. As a practice it can only be understood in the broader stylistic landscape in which it is used.

The insights of the 2005 study would clearly not have been possible to uncover with the variety approach. The variety approach separates groups of speakers from each other based on their ethnic and linguistic inherited backgrounds. Not only does this have the consequence that it takes groups for granted in an almost essentialist sense, it also obscures the possibility of seeing and understanding multiethnolect as a complex practice - as a stylistic practice. Indeed, the variety approach with good reason may be accused of violating a linguistic reality in its attempt to make it fit predefined categories. However, such a "violation" is not entirely destructive. The depiction of systematism, by methods developed in the tradition of dialectology and variationist sociolinguistics, is still needed when the goal is to describe and predict linguistic variation and changes 
in the broader speech community. The 2000 study was an early account of some of the linguistic consequences of migration in Copenhagen. It indicated new linguistic developments that arguably could, in the course of time, influence developments in Danish standard language (Quist, 2000, pp.47-52). Furthermore, as it was argued in the previous sections, the 2005 study of stylistic practices would not have been able to include the multiethnic speech styles in a systematic analysis had it not been for the 2000 study of Copenhagen multiethnolect. In the Scandinavian research context, the variety approach was a necessary precondition for the more constructivist practice approach.

Despite their different goals and methods, both the variety approach and the stylistic practice approach seek to challenge traditional outlines of Copenhagen as a mono-lingual or mono-dialectological speech community. The linguistic situations in multiethnic urban communities are complex and can not be fully grasped if only approached from one research perspective. From different angles, the two studies of Copenhagen multiethnolect show that Copenhagen language use and variation take new forms and meanings in the wake of immigration.

\section{References}

AASHEIM, S. C. (1997). "Kebab-norsk" - fremmedspråklig påvirkning på ungdomsspråket i Oslo. In Kotsinas, Stenström \& Karlson (Eds.), Ungdomsspråk i Norden. MINS 43 (pp. 235-242). Stockholm: Stockholm Universitet.

AUER, P. (2003). "Türkenslang.” Ein jugendsprachlicher Ethnolekt des Deutschen und seine Transformationen. In A. Häcki Buhofer (Hrsg.), Spracherwerb und Lebensalter (pp. 255-264). Tübingen/Basel.

BÓDEN, P. (2004). A new variety of Swedish? In S. Cassidy, F. Cox, R. Mannell \& S. Palethorpe (Eds.), Proceedings of the Tenth Australian International Conference on Speech Science and Technology. Macquarie University, Sydney, 8th-10th December, 2004 (pp.475-480). Sydney: Australian Speech Science and Technology Association (Inc).

BÓDEN, P. (2007). "Rosengårdssvensk" fonetik och fonologi. In L. Ekberg (Ed.), Språket hos ungdomar i en flerspråkig miljö i Malmö. Nordlund. Småskrifter från Nordiska språk i Lund 27. (pp.1-47). Lund: Department of Scandinavian Languages, Lund University.

CHRISTENSEN, M. V. (2004). Arabiske ord i dansk hos unge i multietniske områder i Århus. In S. Dabelsteen \& J. Arnfast (Eds.), Taler de dansk? Aktuel forskning i dansk som andetsprog. Københavnerstudier i tosprogethed, bind 37 (pp. 33-49). Københavns Universitet.

CHRISTENSEN, M. V. (in preparation). Youth and speech in multiethnic Arhus (tentative title). $\mathrm{PhD}$ project. Århus University, Denmark.

CLYNE, M. (2000). Lingua Franca and Ethnolects in Europe and beyond. Sociolinguistica, 14, $83-89$.

DIRIM, I., \& AUER, P. (2004). Türkisch sprechen nicht nur die Türken: über die Unschärfebeziehung zwischen Sprache und Ethnie in Deutschland. Berlin: Walter de Gruyter.

ECKERT, P. (1989). Jocks and burnouts. Social categories and identity in the high school. New York: Teachers College Press.

ECKERT, P. (1996). Vowels and nail polish: The emergence of linguistic style in the preadolescent heterosexual marketplace. In N. Warner et al. (Eds.), Gender and belief systems (pp. 183-190). Berkeley: Berkeley Women and Language Group.

ECKERT, P. (2000). Linguistic variation as social practice. Malden: Blackwell.

ECKERT, P. (2001). Style and social meaning. In P. Eckert \& J. R. Rickford (Eds.), Style and sociolinguistic variation (pp.119-128). Cambridge: Cambridge University Press. 
FRAURUD, K. (2004). Några sociolingvistiska förutsättningar för språklig variation och mångfald i Rinkeby. In B. Melander (Ed.), Svenskans beskrivning 26 (pp. 25-47). Uppsala: Hallgren and Fallgren.

FRAURUD, K., \& BIJVOET, E. (2004). Multietniska ungdomsspråk och andra varieteter av svenska i flerspråkiga miljöer. In K. Hyltenstam \& I. Lindberg (Eds.), Svenska som andraspråk (pp.389-419). Lund: Studentlitteratur.

HANSEN, G. F., \& PHARAO, N. (2005). Prosodiske træk i et- og tosprogede unges københavnsk. Danske talesprog. København: C. A. Reitzels Forlag. 1-50.

KOTSINAS, U. B. (1987). Rinkebysvenskan - en dialekt? In Svenskans Beskrivning 16. (pp. 264-278). Linköping: Tema Kommunikation, Universitetet i Linköping.

KOTSINAS, U. B. (1988). Immigrant children's Swedish - A new variety? Journal of Multilingual and Multicultural Development, 9(1 \& 2), 129-140.

KOTSINAS, U. B. (1992). Immigrant adolescents' Swedish in multicultural areas. In Palmgren et al. (Eds.), Ethnicity in youth culture (pp.43-62). Stockholm: Youth Culture at Stockholm University.

KOTSINAS, U. B. (1996). Rinkebysvenska - ett ungdomsspråk. In Alla vi svenskar. Nordiska Museets och Skansens Årsbok (pp. 29-45). Stockholm: Fataburen.

KOTSINAS, U. B. (1998). Language contact in Rinkeby-a immigrant suburb. In J. K. Androutsopoulos \& A. Scholz (Hrsg.), Jugendsprache, langue des jeunes, youth language (pp. 125-148). Frankfurt am Main: Peter Lang Europäischer Verlag der Wissenschaften.

KOTSINAS, U. B. (2000). Språkkontakt och slangspråk i Stockholm. Ungdommers språkmøter (pp.19-60). København: Nordisk Ministerråd.

QUIST, P. (2000). Ny københavnsk "multietnolekt.” Om sprogbrug blandt unge i sprogligt og kulturelt heterogene miljøer. Danske Talesprog (pp.143-212). Bind 1. Institut for Dansk Dialektforskning. København: C. A. Reitzels Forlag.

QUIST, P. (2005). Stilistiske Praksisser i Storbyens Heterogene Skole. En etnografisk og sociolingvistisk undersogelse af sproglig variation. PhD-af handling. Nordisk Forskningsinstitut, afd. for dialektforskning. Københavns Universitet.

QUIST, P., \& JØRGENSEN, N. J. (2007). Crossing — negotiating social boundaries. In P. Auer \& Li Wei. (Eds.), Handbook of Multilingualism and Multilingual Communication (pp. 371-389). Berlin: Mouton de Gruyter.

SØNDERGAARD, D. M. (2000). Tegnet på kroppen. København: Museum Tusculanums Forlag. UPUS — <http://www.hf.ntnu.no/hfladm/forskning/prosjekter/UPUS/index.html>.

WENGER, E. (1998). Communities of practice. Learning, meaning and identity. Cambridge: Cambridge University Press.

\section{Appendix}

\section{Masculine style clusters}

(1) White skin, masculine body sign; "Dane"; show no to little interest in class teaching; use computers for games, chat and music; smoke; leave the school premises during lunch breaks; drink alcohol and talk about it in class; wear hip-hop clothes / baggy jeans and large T-shirts; images of naked women as computer wallpaper; listen to hip-hop and rock music.

Long (t). Frequent use of 'lexis' — mostly slang and swear-words. $\div$ use multiethnolectal features. 
(2) Brown skin, masculine body sign; "foreigner"; show no to little interest in class teaching; use computers for games, chat and music; hang out in the hallway between the classrooms; images of cars as computer wallpaper; clothes: polo-shirts and jeans; music: radio chart hits.

$\div$ long (t). Multiethnolectal features.

(3) Brown or white skin; masculine body sign; signals involvement in class teaching; use computers for school work; nonsmoker; stay in the class room during breaks; don't drink alcohol; clothes: polo-shirts and jeans; (wallpaper: cars / humor/other, i.e., not naked women).

$\div$ long $(\mathrm{t}) . \div$ frequent use of slang and swear words. $\div$ use multiethnolectal features.

\section{Feminine style clusters}

(4) White skin, feminine body sign; "Dane"; show neither antischool attitude nor special involvement in class teaching; use computers for chat and school work; hang out in the hallway or the courtyard; nonsmoker; clothes: urban, relaxed.

$\div$ long (t). $\div$ frequent use of 'lexis'. $\div$ use multiethnolectal features.

(5) White skin, feminine body sign; "Dane"; show neither antischool attitude nor special involvement in class teaching; use computers for chat and school work; stay in the classroom during breaks; no relations to parallel classes; nonsmoker; clothes: bright pop; computer wallpaper: male idol.

$\div$ long (t). $\div$ frequent use of 'lexis'. $\div$ use multiethnolectal features.

(6) Brown skin; feminine body sign; "foreigner"; show neither antischool attitude nor special involvement in class teaching; use computers for chat and school work; move between the class rooms of 1.a and 1.x; nonsmokers; music: ethnic pop and hip-hop; clothes: dark pop; computer wallpaper: male idol.

Multiethnolectal features

(7) Brown skin; feminine body sign; "scarf girl"; signals involvement in class teaching; use computers for school work; nonsmoker; stay in the classroom during breaks; clothes: hidjâb; computer wallpaper: landscapes, Arabic signs.

$\div$ long (t). $\div$ frequent use of 'lexis'. $\div$ use multiethnolectal features. 